\title{
Sistem Pendukung Keputusan Dalam Menentukan Jenis Pohon Pelindung Yang Akan di Tanam Dipinggir Jalan Menggunakan Metode Promethee II
}

\author{
Ardian Fadly Telaumbanua, Muhammad Syahrizal, Murdani* \\ Program Studi Teknik Informatika, STMIK Budi Darma, Medan, Indonesia \\ Email: ardianfadlyteumbanua@gmail.com
}

\begin{abstract}
Abstrak-Pohon pelindung merupakan sekelompok tanaman yang memiliki tajuk panjang dan berdaun lebat serta berbatang cukup tinggi untuk dijadikan peneduh. Biasanya pohon pelindung menjadi tanaman utama di sebuah taman. Namun yang paling sering kita lihat adalah pohon pelindung yang ditanam disepanjang jalan. Fungsinya selain sebagai pohon peneduh juga dimaksudkan untuk menyerap polusi. Diperlukan mementukan pemilihan jenis pohon pelindung yang terbaik untuk di tanam dipinggir jalan. Pemilihan jenis pohon pelindung masih menggunakan sistem manual dan membutuhkan waktu yang cukup lama. Berdasarkan masalah tersebut, dibutuhkan suatu sistem pendukung keputusan (SPK) yang dapat memudahkan dalam pemilihan jenis pohon pelindung yang terbaik dengan menggunakan kriteria-kriteria yang ada. Salah satu metode yang dapat digunakan adalah Preference Ranking Orgainization Method for Enrichment Evaluation II (PROMETHEE II). Metode ini mampu memecahkan jenis masalah apapun dalam pengambilan keputusan dengan alternatif dan kriteria yang telah diberikan bobotnya Penelitian menggunakan PROMETHEE II menghasilkan komposisi pohon pelindung yang biasa hingga pohon pelindung yang terbaik. Sistem pemilihan pohon pelindung dibangun dengan menggunakan Microsoft Visual Studio 2008 dan Microsoft Access 2010 sebagai database.
\end{abstract}

Kata Kunci: Sistem Pendukung Keputusan, PROMETHEE II, Pohon Pelindung.

Abstract-A protective tree is a group of plants that have long canopy and thick leaves and trunk high enough to be a shade. Usually a protective tree becomes the main plant in a park. But what we often see is the protective tree planted along the road. Its function aside from being a shade tree is also intended to absorb pollution. It is necessary to determine the selection of the best tree species to be planted on the side of the road. The selection of protective tree species still uses a manual system and requires quite a long time. Based on these problems, we need a decision support system (SPK) that can facilitate the selection of the best protective tree species using existing criteria. One method that can be used is the Preference Ranking Organization Method for Enrichment Evaluation II (PROMETHEE II). This method is able to solve any type of problem in decision making with alternatives and criteria that have been given weight. Research using PROMETHEE II produces the composition of the usual protective trees to the best protective trees. The protective tree selection system was built using Microsoft Visual Studio 2008 and Microsoft Access 2010 as a database.

Keywords: Decision Support System, PROMETHEE II, Tree Protection.

\section{PENDAHULUAN}

Sistem pendukung keputusan menurut Keen dan Scoot Morton adalah sebagai berikut, sistem pendukung keputusan merupakan pasangan intelektual dari sumber daya manusia dengan kemampuan komputer untuk memperbaiki keputusan, yaitu sitem pendukung keputusan berbasis komputer bagi pembuat keputusan manajemen yang menghadapi masalah semi terstruktur, sistem pendukung keputusan sebagai kumpulan prosedur basis model untuk memproses data dan keputusan guna membantu manajer dalam membuat keputusan[1].

Pohon pelindung merupakan sekelompok tanaman yang memiliki tajuk panjang dan berdaun lebat serta berbatang cukup tinggi untuk dijadikan peneduh. Biasanya pohon pelindung menjadi tanaman utama di sebuah taman. Namun yang paling sering kita lihat adalah pohon pelindung yang ditanam disepanjang jalan. Fungsinya selain sebagai pohon peneduh juga dimaksudkan untuk menyerap polusi. Ada banyak jenis tanaman yang dapat digunakan sebagai pohon pelindung. Beberapa jenis pohon pelindung bahkan ada yang berbunga indah, seperti pohon dadap merah ( Erythrina Crista-galli) dan pohon cempaka wangi berbunga kuning ( Magnolia champaca syn. Michelia champaca) serta pohon cempaka putih ( Magnolia champaca syn. Michelia alba)[2].

Proses pemilihan tanaman pohon pelindung di pinggir jalan masih bersifat manualisasi tanpa adanya peranan suatu sistem komputerisasi. Sering terjadi kesalahan-kesalahan dalam pemilihan tanaman pohon pelindung dipinggir jalan,yaitu kesalahan dalam memilih kriteria-kriteria tanaman pohon pelindung yang di nilai kurang efektif dan akan menimbulkan kesalahan jenis tanaman di kemudian hari,sebab akar pohon pelindung yang salah ditanam kurang kokoh akarnya dan mengakibatkan pohon tumbang karena hembusan angin dan hujan deras. Berdasarkan permasalahan tersebut, diperlukan sebuah sistem pendukung keputusan dalam menentukan jenis pohon pelindung di pinggir jalan.

Metode PROMETHEE merupakan salah satu teknik perhitungan Multi Criteria Decision Making (MCDM) yang dikembangkan oleh Brans dan Vincke pada tahun 1985. Masalah pokoknya adalah kesederhanaan, kejelasan, dan kestabilan. Dugaan dari dominasi kriteria yang digunakan dalam promethee II adalah penggunaan nilai dalam hubungan outranking. Ini adalah metode peringkat yang cukup sederhana dalam konsep dan aplikasi dibandingkan dengan metode lain untuk analisis multikriteria[3].

Penelitian sebelumnya yang dilakukan oleh muhammad wafi tahun 2017 vol 1 no. 11 issue : 11 nama jurnal : Pengembangan teknologi informasi dan ilmu komputer e-ISSN: 2548-964X tentang implementasi metode 
Promethee II untuk menentukan pemenang tender proyek. Penelitian ini dilakukan untuk mempermudah Dinas Perhubungan dalam menentukan pemenang tender sehingga memberikan hasil yang lebih akurat[4].

Penelitian pada SPK yang dilakukan oleh Priranda widara ananta tahun 2013 vol 1 no. 2 issue : 11 nama jurnal : Sarjana teknik informatika e-ISSN: 2338-5197 tentang Sistem Pendukung Keputusan Dalam Penilaian Kinerja Pegawai Untuk Kenaikan Jabatan Pegawai Menggunakan Metode GAP Kompetensi. Mendefinisikan sistem pendukung keputusan sebagai kumpulan prosuder baris model untuk memproses data dan keputusan guna membantu manajer dalam membuat keputusan[1].

\section{METODE PENELITIAN}

\subsection{Sistem Pendukung Keputusan}

Sistem Pendukung Keputusan (Decision Support System)adalah suatu sistem yang memiliki kemampuan dalam pemecahan masalah / komunikasi untuk kondisi masalah yang terstruktur maupun tidak terstruktur yang mempunyai peran dalam membantu pemecahan masalah dan tidak satupun yang mengetahui bagaimana keputusan yang seharusnya dibuat[5]-[8].

\subsection{Pohon Pelindung}

Pohon Pelindung adalah sekelompok tanaman yang memiliki tajuk panjang dan berdaun lebat serta berbatang cukup tinggi untuk dijadikan peneduh. Biasanya pohon pelindung menjadi tanaman utama di sebuah taman. Namun yang paling sering kita lihat adalah pohon pelindung yang ditanam sepanjang jalan. Fungsinya selain sebagai pohon peneduh juga dimaksudkan untuk menyerap polusi.

Ada banyak jenis tanaman yang dapat digunakan sebagai pohon pelindung. Beberapa jenis pohon pelindung bahkan ada yang berbunga indah, seperti pohon dada merah (Erythrina crista-galli) dan pohon cempaka wangi berbunga kuning (Magnolia champaca syn. Michelia champaca) serta pohon cempaka putih (Magnolia champaca syn. Michelia alba)[2].

\subsection{Metode Promethee II}

Metode PROMETHEE merupakan salah satu teknik perhitungan Multi Criteria Decision Making (MCDM) yang dikembangkan oleh Brans dan Vincke pada tahun 1985[3]. Metode PROMETHEE merupakan metode yang efesien dansederhana, sehingga mudah diterapkan dalam menyelesaikan pengambilan keputusan atau multikriteria. Metode PROMETHEE dapat mengakomodasi pemilihan kriteria dari kuantitatif hingga kulitatif[9]. Permasalahan dari kriteria dalam metode PROMETHEE adalah penggunaan nilai yang berkaitan dengan outrangking [4], [10]-[13].

Menurut Timohir Hunjak dalam bukunya yang berjudul Mathematical Foundations of the Methods for MCMD menjelaskan tiga tahapan PROMETHEE, yaitu[14]:

1. Mengumpul stiap preferensi, yakni menguraikan kriteria sebagai bahan pertimbangan dalam penilaian alternatif dari kriteria yang ada.

2. Mengumpul relasi atau hubungan yang menonjol dengan membuatnya berdasarkan penilaian alternatif dari keriteria yang ada. Tingkatan dari preferensi merupakan alternatif yang paling menonjol berdasarkan perhitungan masing-masing alternatif.

3. Menganalisa keputusan yakni memberikan informasi atau data peringkat masing-masing alternatif. PROMETHEE I memberikan peringkat sebagian dari set A, sedangkan PROMETHEE II memberikan peringkat yang lengkat dari set $\mathrm{A}$.

Tabel 1. Data Evaluasi

\begin{tabular}{|c|c|c|c|c|c|c|}
\hline $\mathbf{a}_{\mathbf{x}}$ & $\mathbf{f}_{1}()$ & $\mathbf{f}_{2}()$ & .............. & $\mathbf{f}_{\mathbf{j}}(\mathbf{)}$ & .......... & $\mathbf{f}_{\mathrm{k}}()$ \\
\hline$a_{1}$ & $f_{1}\left(a_{1}\right)$ & $f_{2}\left(a_{1}\right)$ & $\ldots \ldots \ldots$ & $\mathrm{f}_{\mathrm{j}}\left(\mathrm{a}_{1}\right)$ & $\ldots \ldots \ldots$ & $\mathrm{f}_{\mathrm{k}}\left(\mathrm{a}_{1}\right)$ \\
\hline$a_{2}$ & $\mathrm{f}_{1}\left(\mathrm{a}_{2}\right)$ & $\mathrm{f}_{2}\left(\mathrm{a}_{2}\right)$ & ......... & $\mathrm{f}_{\mathrm{j}}\left(\mathrm{a}_{2}\right)$ & $\ldots \ldots \ldots$ & $\mathrm{f}_{\mathrm{k}}\left(\mathrm{a}_{2}\right)$ \\
\hline ....... & ........ & ....... & ........ & $\ldots \ldots$ & n........ & $\ldots \ldots$ \\
\hline$a_{i}$ & $\mathrm{f}_{1}\left(\mathrm{a}_{\mathrm{i}}\right)$ & $\mathrm{f}_{2}\left(\mathrm{a}_{\mathrm{i}}\right)$ & $\ldots \ldots \ldots$ & $\mathrm{f}_{\mathrm{j}}\left(\mathrm{a}_{\mathrm{i}}\right)$ & & $\mathrm{f}_{\mathrm{k}}\left(\mathrm{a}_{\mathrm{i}}\right)$ \\
\hline$\ldots \ldots$ & $\ldots \ldots \ldots$ & $\ldots \ldots$ & ........ & ........ & ........ & ........ \\
\hline$a_{n}$ & $\mathrm{f}_{1}\left(\mathrm{a}_{\mathrm{n}}\right)$ & $\mathrm{f}_{2}\left(\mathrm{a}_{\mathrm{n}}\right)$ & ......... & $\mathrm{f}_{\mathrm{j}}\left(\mathrm{a}_{\mathrm{n}}\right)$ & $\ldots$. & $\left.\begin{array}{ll}f_{k} & a_{n}\end{array}\right)$ \\
\hline
\end{tabular}

Sumber:Tihomir Hunjak 1997[14]

Dimana:

ai : alternatif $\mathrm{i}$

fk (ai) : kriteria yang ditetapkan untuk alternatif i

Strukutur preferensi yang dibangun atas dasar kriteria: 
$\forall a, b \in A f(a), f(b)\} f(a)>f(b)$

$a P b f(a)=f(b) \quad a I b$

Struktur kriteria di atas memiliki arti yakni setiap alternatif a dan elemen himpunan A, jika nilai alternatif a sebagai kriteria yang ditetapkan untuk alternatif a lebih dari nilai alternatif $b$, maka alternatif a lebih dipilih (prefer) daripada alternatif $\mathrm{b}$, sedangkan jika nilai alternatif a sama dengan nilai alternatif $\mathrm{b}$, maka disimpulkan bahwa alternatif a tidak mempunyai perbedaan (indifference) dengan fungsi $b$, sehingga untuk menentukan alternatif mana yang lebih diprioritaskan harus mengamati nilai dari alternatif lainnya.

Metode PROMETHEE I dapat menyediakan perangkingan keputusan alternatif sebagian, sedangkan metode PROMETHEE II dapat memperoleh peringkat penuh alternatif. Adapun langkah-langkah proses perangkingan dalam metode PROMETHE II ialah[3]:

1. Menentukan normalisasi matriks keputusan dengan menggunakan persamaan berikut:

$R_{i j}=\frac{x_{i j}-\min \left(X_{i j}\right)}{\max \left(X_{i j}\right)-\min \left(X_{i j}\right)}(i=1,2, \ldots, n ; j=1,2, \ldots, m)$

Dimana nilai $X_{i j}$ merupakan ukuran kinerja alternatif sesuai dengan kriteria j yang telah ada. Untuk kriteria non-benefit dapat menggunakan rumus:

$R_{i j}=\frac{\max \left(X_{i j}\right)-\left(X_{i j}\right)}{\max \left(X_{i j}\right)-\min \left(X_{i j}\right)}(i=1,2, \ldots, n ; j=1,2, \ldots, m)$

2. Menghitung perbedaan evaluatif dari alternatif dengan alternatif lainnya. Langkah ini melibatkan perhitungan perbedaan dari nilai-nilai kriteria antara alternatif pasangan yang berbeda.

3. Menghitung fungsi preferensi, $P_{j}\left(i, i^{\prime}\right)$.

$P_{i j}\left(i, i^{\prime}\right)=0$ if $R_{i j} \leq R_{i^{\prime} j}$

$P_{j}\left(i, i^{\prime}\right)=\left(R_{i j}-R_{i^{\prime} j}\right)$ if $R_{i j}>R_{i^{\prime} j}$

4. Menghitung fungsi preferensi gabungan dengan memperhatikan bobot kriteria. Fungsi untuk preferensi gabungan,

$\pi\left(i, i^{\prime}\right)=\frac{\left[\sum_{j=1}^{m} w_{j} \times P_{j}\left(i, i^{\prime}\right)\right]}{\sum_{j=1}^{m} w_{j}}$

Dimana $w_{j}$ adalah relatif kriteria (berat) penting dari kriteria j.

5. Menentukan aliran keluar dan masuk outranking dengan rumus:

Leaving Flow (altenatif positif),

$\varphi^{+}(i)=\frac{1}{n-1} \sum_{i^{\prime}=1}^{n} \pi\left(i, i^{\prime}\right) \quad\left(i \neq i^{\prime}\right)$

Entering Flow (altenatif negatif),

$\varphi^{-}(i)=\frac{1}{n-1} \sum_{i^{\prime}=1}^{n} \pi\left(i^{\prime}, i\right) \quad\left(i \neq i^{\prime}\right)$

Dimana n merupakan jumlah alternatif yang digunakan. Pada langkah ini, setiap alternatif (n-1) jumlah alternatif. Leaving flow (positif) menunjukkan alternatif yang mendominasi diantara alternatif lain, sedangkan entering flow (negatif) menunjukkan beberapa alternatif yang didominasi oleh alternatif-alternatif lain.

6. Menghitung total seluruh outranking (leaving dan entering flow) pada setiap alternatif.

$$
\varphi(i)=\varphi^{+}(i)-\varphi^{-}(i)
$$

7. Melakukan perangkingan berdasarkan nilai $\varphi$ (i), jika lebih tinggi dari $\varphi$ (i), maka alternatif semakin baik. Alternatif terbaik adalah alternatif dengan nilai $\varphi$ (i) tertinggi.

\section{HASIL DAN PEMBAHASAN}

Dalam menentukan jenis pohon pelindung terbaik, beberapa jenis pohon akan dijadikan sebagai pertimbangan. Dengan penerapan sistem pendukung keputusan dapat membantu menghasilkan alternatif dan kriteria yang tepat sesuai dengan kebutuhan.

Tabel 2. Data Pohon

\begin{tabular}{lcclc}
\hline \multicolumn{1}{c}{ Nama Pohon } & Umur & Jenis Akar & Diameter pohon & Tinggi Pohon \\
\hline Pohon mahoni & 2 Tahun & Akar Gantung & $15 \mathrm{~cm}$ & $6 \mathrm{~m}$ \\
Pohon Trambesi & 1,5 Tahun & Akar Serabut & $8 \mathrm{~cm}$ & $3 \mathrm{~m}$ \\
Pohon Tanjung & 1 Tahun & Akar Tunggang & $7 \mathrm{~cm}$ & $3 \mathrm{~m}$ \\
Pohon Akasia & 1,5 Tahun & Akar Gantung & $10 \mathrm{~cm}$ & $5 \mathrm{~m}$ \\
Pohon Angsana & 2 Tahun & Akar Tunggang & $7 \mathrm{~cm}$ & $4 \mathrm{~m}$ \\
Pohon Flamboyan & 1 Tahun & Akar Serabut & $16 \mathrm{~cm}$ & $6 \mathrm{~m}$ \\
\hline
\end{tabular}

\subsection{Alternatif}

Data alternatif berperan penting dalam proses pemilihan jenis pohon pelindung. Alternatif yang dipilih merupakan alternatif yang direkomendasikan oleh pihak Dinas pertamanan kota medan agar data tersebut lebih akurat dan terpercaya. Beberapa alternatif-alternatif yang dimaksud dapat dilihat pada tabel 3 berikut. 
Tabel 3. Data alternatif Jenis Pohon

\begin{tabular}{cc}
\hline Alternatif $(\mathbf{A})$ & Keterangan \\
\hline $\mathrm{A}_{1}$ & Pohon Mahoni \\
$\mathrm{A}_{2}$ & Pohon Trambesi \\
$\mathrm{A}_{3}$ & Pohon Tanjung \\
$\mathrm{A}_{4}$ & Pohon Akasia \\
$\mathrm{A}_{5}$ & Pohon Angsana \\
$\mathrm{A}_{6}$ & Pohon Flamboyan \\
\hline
\end{tabular}

\subsection{Kriteria}

Dalam Proses metode PROMETHEE II memerlukan kriteria-kriteria yang akan dijadikan bahan perhitungan dan pertimbangan untuk mencapai perangkingan dalam menentukan kelayakan jenis pohon pelindung yang akan ditanam dipinggir jalan pada Dinas Pertamanan Kota Medan. Adapun kriteria-kriteria yang menjadi bahan perhitungan dan pertimbangan dapat dilihat pada tabel 4.

Tabel 4. Kriteria

\begin{tabular}{cc}
\hline Kriteria & Keterangan \\
\hline C1 & Umur \\
C2 & Jenis Akar \\
C3 & Diameter Pohon \\
C4 & Tinggi pohon \\
\hline
\end{tabular}

\subsection{Fuzzy}

Dilihat dari masing-masing kriteria di atas akan ditentukan bobot-bobotnya. Untuk mendapat variabel tersebut harus digambarkan dalam sebuah grafik yang dapat dilihat dari gambar 1. berikut.

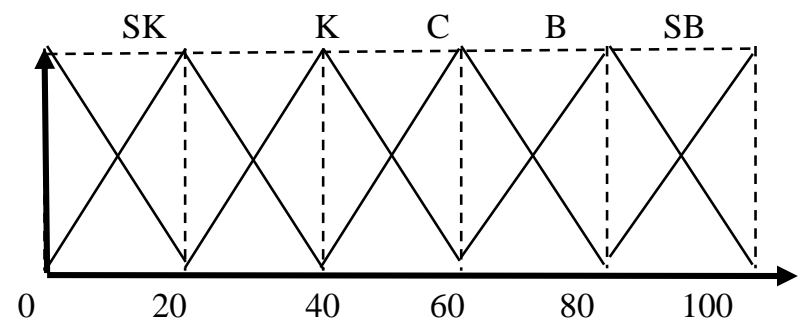

Keterangan:
SK: Sangat Kurang
K: Kurang
C: Cukup

Gambar 1. Grafik Fuzzy Bobot

Dari gambar di atas, bilangan-bilangan fuzzy dapat dikonversikan ke bentuk bilangan crisp. Untuk lebih jelas data bobot dibentuk dalam tabel berikut:

Tabel 5. Bobot

\begin{tabular}{cc}
\hline Bilangan fuzzy & Nilai \\
\hline Sangat Kurang & $0-20$ \\
Kurang & $21-40$ \\
Cukup & $41-60$ \\
Baik & $61-80$ \\
Sangat Baik & $81-100$ \\
\hline
\end{tabular}

1. Umur

sebagai pohon pelindung kita harus mengetahui umur dari pohon tersebut, maka dapat dilihat pada tabel 6

Tabel 6. Kriteria Umur

\begin{tabular}{ccc}
\hline Umur $(\mathrm{C} 1)$ & Keterangan & Nilai \\
\hline 1 Tahun & Cukup & $41-60$ \\
1,5 Tahun & Baik & $61-80$ \\
2 Tahun & Sangat Baik & $81-100$ \\
\hline
\end{tabular}

2. Jenis Akar

Dinas Pertamanan kota medan harus mengetahui jenis akar yang ditanam, dapat dilihat pada tabel 7 
Tabel 7. Kriteria Akar pondasi

\begin{tabular}{ccc}
\hline Akar pondasi (C2) & Keterangan & Nilai \\
\hline Akar Gantung & Rendah & $21-40$ \\
Akar Serabut & Cukup & $41-60$ \\
Akar Tunggang & Sangat Baik & $81-100$ \\
\hline
\end{tabular}

3. Diameter Pohon

Bagi kepala dinas pertamanan harus mengetahui diameter pohon,agar mengetahui diameter pohon yang ditanam secara tepat. Agar tidak merusak draineser, maka dapat dilihat pada tabel 8

Tabel 8. Kriteria Diameter Pohon

\begin{tabular}{ccc}
\hline Diameter Pohon $(\mathrm{C} 3)$ & Keterangan & Nilai \\
\hline $7-10 \mathrm{~cm}$ & Baik & $61-80$ \\
$10-13 \mathrm{~cm}$ & Sangat Baik & $81-100$ \\
$13-16 \mathrm{~cm}$ & Sangat Baik & $81-100$ \\
\hline
\end{tabular}

\section{Tinggi Pohon}

Dinas Pertamanan harus mengetahui tinggi pohon yang akan di tanam dipinggir jalan ,maka dari itu dapat dilihat pada tabel 9

Tabel 9. Tinggi Pohon

\begin{tabular}{ccc}
\hline Tinggi pohon $(\mathrm{C} 4)$ & Keterangan & Nilai \\
\hline $1-2 \mathrm{~m}$ & Cukup & $41-60$ \\
$2-4 \mathrm{~m}$ & Baik & $61-80$ \\
$4-6 \mathrm{~m}$ & Baik & $61-80$ \\
\hline
\end{tabular}

Berdasarkan Kriteria diatas maka rating kecocokan yang di peroleh adalah :

Tabel 10. Rating Kecocokan

\begin{tabular}{ccccc}
\hline $\mathbf{A}$ & $\mathbf{C}_{\mathbf{1}}$ & $\mathbf{C}_{\mathbf{2}}$ & $\mathbf{C}_{\mathbf{3}}$ & $\mathbf{C}_{\mathbf{4}}$ \\
\hline $\mathrm{A}_{1}$ & 95 & 25 & 60 & 45 \\
$\mathrm{~A}_{2}$ & 80 & 42 & 16 & 16 \\
$\mathrm{~A}_{3}$ & 55 & 64 & 60 & 16 \\
$\mathrm{~A}_{4}$ & 80 & 25 & 39 & 40 \\
$\mathrm{~A}_{5}$ & 95 & 64 & 16 & 45 \\
$\mathrm{~A}_{6}$ & 55 & 42 & 60 & 45 \\
$\mathbf{M a x}$ & $\mathbf{9 5}$ & $\mathbf{6 4}$ & $\mathbf{6 0}$ & $\mathbf{4 5}$ \\
$\mathbf{M i n}$ & $\mathbf{5 5}$ & $\mathbf{2 5}$ & $\mathbf{1 6}$ & $\mathbf{1 6}$ \\
\hline
\end{tabular}

Berdasarkan tabel kecocokan alternatif dan kriteria, maka matriks keputusan yang diperoleh adalah:

$$
\left[\begin{array}{llll}
95 & 25 & 60 & 45 \\
80 & 42 & 16 & 16 \\
55 & 64 & 60 & 16 \\
80 & 25 & 39 & 40 \\
95 & 64 & 16 & 45 \\
55 & 42 & 60 & 45
\end{array}\right]
$$

Penentuan bobot preferensi (standart nilai) yang merupakan nilai bobot ketentuan yang diberikan oleh Dinas Pertamanan Kota Medan dapat dilihat pada tabel 11

Tabel 11. Bobot $\mathrm{W}$

\begin{tabular}{cc}
\hline Keterangan & Bobot W \\
\hline Umur & $25 \%$ \\
Jenis Akar & $35 \%$ \\
Diameter Pohon & $15 \%$ \\
Tinggi Pohon & $25 \%$ \\
\hline
\end{tabular}

Bobot $=(0,25,0,35,0,15,0,25=1) \mathrm{n}=4$

Langkah 1 : Menentukan normalisasi matriks keputusan

$R_{i j}=\frac{X_{i j}-\min \left(X_{i j}\right)}{\max \left(X_{i j}\right)-\min \left(X_{i j}\right)}$

Normalisasi matriks kolom 1 
$R_{11}=\frac{95-55}{95-55}=\frac{40}{40}=1$

$R_{21}=\frac{80-55}{95-55}=\frac{25}{40}=0.625$

$R_{31}=\frac{55-55}{95-55}=\frac{0}{40}=0$

$R_{41}=\frac{80-55}{95-55}=\frac{25}{40}=0.625$

$R_{51}=\frac{95-55}{95-55}=\frac{40}{40}=1$

$R_{61}=\frac{55-55}{95-55}=\frac{0}{40}=0$

Maka normalisasi matriks keputusan yang diperoleh sebagai berikut:

$X=\left[\begin{array}{cccc}1 & 0 & 1 & 1 \\ 0.625 & 0.435 & 0 & 0 \\ 0 & 1 & 1 & 0 \\ 0.625 & 0 & 0.522 & 0.827 \\ 1 & 1 & 0 & 1 \\ 0 & 0.435 & 1 & 1\end{array}\right]$

Langkah 2 : Menghitung fungsi preferensi, $P_{j}\left(i, i^{\prime}\right)$.

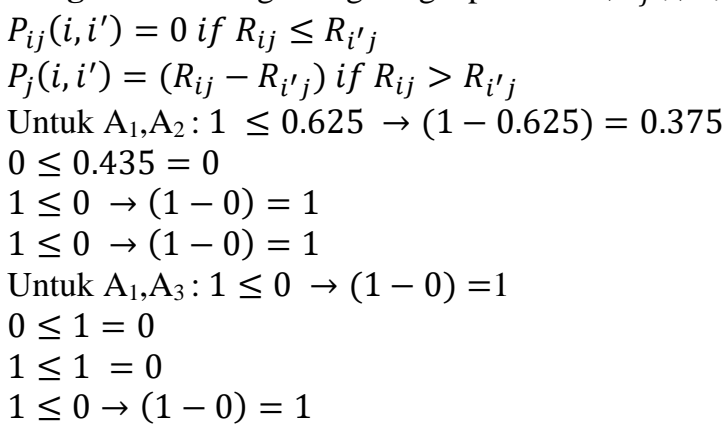

Tabel 12. Fungsi Preferensi Semua Pasangan Alternatif

\begin{tabular}{ccccc}
\hline Alternatif & $\mathbf{C}_{\mathbf{1}}$ & $\mathbf{C}_{\mathbf{2}}$ & $\mathbf{C}_{\mathbf{3}}$ & $\mathbf{C}_{\mathbf{4}}$ \\
\hline $\mathrm{A}_{1}, \mathrm{~A}_{2}$ & 0.375 & 0 & 1 & 1 \\
$\mathrm{~A}_{1}, \mathrm{~A}_{3}$ & 1 & 0 & 0 & 1 \\
$\mathrm{~A}_{1}, \mathrm{~A}_{4}$ & 0.375 & 0 & 0.478 & 0.173 \\
$\mathrm{~A}_{1}, \mathrm{~A}_{5}$ & 0 & 0 & 1 & 0 \\
$\mathrm{~A}_{1}, \mathrm{~A}_{6}$ & 1 & 0 & 0 & 0 \\
$\mathrm{~A}_{2}, \mathrm{~A}_{1}$ & 0 & 0.435 & 0 & 0 \\
$\mathrm{~A}_{2}, \mathrm{~A}_{3}$ & 0.625 & 0 & 0 & 0 \\
$\mathrm{~A}_{2}, \mathrm{~A}_{4}$ & 0 & 0.435 & 0 & 0 \\
$\mathrm{~A}_{2}, \mathrm{~A}_{5}$ & 0 & 0 & 0 & 0 \\
$\mathrm{~A}_{2}, \mathrm{~A}_{6}$ & 0.625 & 0 & 0 & 0 \\
$\mathrm{~A}_{3}, \mathrm{~A}_{1}$ & 0 & 1 & 0 & 0 \\
$\mathrm{~A}_{3}, \mathrm{~A}_{2}$ & 0 & 0.565 & 1 & 0 \\
$\mathrm{~A}_{3}, \mathrm{~A}_{4}$ & 0 & 1 & 0.478 & 0 \\
$\mathrm{~A}_{3}, \mathrm{~A}_{5}$ & 0 & 0 & 1 & 0 \\
$\mathrm{~A}_{3}, \mathrm{~A}_{6}$ & 0 & 0.565 & 0 & 0 \\
$\mathrm{~A}_{4}, \mathrm{~A}_{1}$ & 0 & 0 & 0 & 0 \\
$\mathrm{~A}_{4}, \mathrm{~A}_{2}$ & 0 & 0 & 0.522 & 0.827 \\
$\mathrm{~A}_{4}, \mathrm{~A}_{3}$ & 0.625 & 0 & 0 & 0.827 \\
$\mathrm{~A}_{4}, \mathrm{~A}_{5}$ & 0 & 0 & 0.522 & 0 \\
$\mathrm{~A}_{4}, \mathrm{~A}_{6}$ & 0.625 & 0 & 0 & 0 \\
$\mathrm{~A}_{5}, \mathrm{~A}_{1}$ & 0 & 1 & 0 & 0 \\
$\mathrm{~A}_{5}, \mathrm{~A}_{2}$ & 0.375 & 0.565 & 0 & 1 \\
$\mathrm{~A}_{5}, \mathrm{~A}_{3}$ & 1 & 0 & 0 & 1 \\
$\mathrm{~A}_{5}, \mathrm{~A}_{4}$ & 0.375 & 1 & 0 & 0.173 \\
$\mathrm{~A}_{5}, \mathrm{~A}_{6}$ & 1 & 0.565 & 0 & 0 \\
\hline & & & &
\end{tabular}




\begin{tabular}{ccccc}
\hline Alternatif & $\mathbf{C}_{\mathbf{1}}$ & $\mathbf{C}_{\mathbf{2}}$ & $\mathbf{C}_{\mathbf{3}}$ & $\mathbf{C}_{\mathbf{4}}$ \\
\hline $\mathrm{A}_{6}, \mathrm{~A}_{1}$ & 0 & 0.435 & 0 & 0 \\
$\mathrm{~A}_{6}, \mathrm{~A}_{2}$ & 0 & 0 & 1 & 1 \\
$\mathrm{~A}_{6}, \mathrm{~A}_{3}$ & 0 & 0 & 0 & 1 \\
$\mathrm{~A}_{6}, \mathrm{~A}_{4}$ & 0 & 0.435 & 0.428 & 0.173 \\
$\mathrm{~A}_{6}, \mathrm{~A}_{5}$ & 0 & 0 & 1 & 0 \\
\hline
\end{tabular}

Langkah 3 : Menghitung fungsi preferensi gabungan dengan bobot ð(i, $\left.i^{\prime}\right)=\frac{\left[\sum_{j=1}^{m} w_{j} \times P_{j}\left(i, i^{\prime}\right)\right]}{\sum_{j=1}^{m} w_{j}}$

Untuk $\mathrm{A}_{1}, \mathrm{~A}_{2}:(0.375 * 0.25) / 1=0.093$

$(0 * 0.35) / 1=0$

$(1 * 0.15) / 1=0.15$

$(1 * 0.25) / 1=0.25$

Untuk $\mathrm{A}_{1}, \mathrm{~A}_{3}:(1 * 0.25) / 1=0.25$

$(0 * 0.35) / 1=0$

$(0 * 0.15) / 1=0$

$(1 * 0.25) / 1=0.25$

Tabel 13. Fungsi Preferensi Gabungan

\begin{tabular}{|c|c|c|c|c|}
\hline Alternatif & $\mathrm{C}_{1}$ & $\mathrm{C}_{2}$ & $\mathrm{C}_{3}$ & $\mathrm{C}_{4}$ \\
\hline $\mathrm{A}_{1}, \mathrm{~A}_{2}$ & 0.093 & 0 & 0.15 & 0.25 \\
\hline$A_{1}, A_{3}$ & 0.25 & 0 & 0 & 0.25 \\
\hline $\mathrm{A}_{1}, \mathrm{~A}_{4}$ & 0.093 & 0 & 0.071 & 0.043 \\
\hline $\mathrm{A}_{1}, \mathrm{~A}_{5}$ & 0 & 0 & 0.15 & 0 \\
\hline $\mathrm{A}_{1}, \mathrm{~A}_{6}$ & 0.25 & 0 & 0 & 0 \\
\hline $\mathrm{A}_{2}, \mathrm{~A}_{1}$ & 0 & 0.152 & 0 & 0 \\
\hline $\mathrm{A}_{2}, \mathrm{~A}_{3}$ & 0 & 0.218 & 0 & 0 \\
\hline $\mathrm{A}_{2}, \mathrm{~A}_{4}$ & 0 & 0.152 & 0 & 0 \\
\hline$A_{2}, A_{5}$ & 0 & 0 & 0 & 0 \\
\hline$A_{2}, A_{6}$ & 0.156 & 0 & 0 & 0 \\
\hline $\mathrm{A}_{3}, \mathrm{~A}_{1}$ & 0 & 0.35 & 0 & 0 \\
\hline$A_{3}, A_{2}$ & 0 & 0.197 & 0.15 & 0 \\
\hline$A_{3}, A_{4}$ & 0 & 0.35 & 0.071 & 0 \\
\hline$A_{3}, A_{5}$ & 0 & 0 & 0.15 & 0 \\
\hline$A_{3}, A_{6}$ & 0 & 0.197 & 0 & 0 \\
\hline $\mathrm{A}_{4}, \mathrm{~A}_{1}$ & 0 & 0 & 0 & 0 \\
\hline $\mathrm{A}_{4}, \mathrm{~A}_{2}$ & 0 & 0 & 0.078 & 0.206 \\
\hline $\mathrm{A}_{4}, \mathrm{~A}_{3}$ & 0.156 & 0 & 0 & 0.206 \\
\hline $\mathrm{A}_{4}, \mathrm{~A}_{5}$ & 0 & 0 & 0.078 & 0 \\
\hline $\mathrm{A}_{4}, \mathrm{~A}_{6}$ & 0.156 & 0 & 0 & 0 \\
\hline $\mathrm{A}_{5}, \mathrm{~A}_{1}$ & 0 & 0.35 & 0.144 & 0 \\
\hline$A_{5}, A_{2}$ & 0.093 & 0.197 & 0 & 0.25 \\
\hline $\mathrm{A}_{5}, \mathrm{~A}_{3}$ & 0.25 & 0.35 & 0.15 & 0.25 \\
\hline $\mathrm{A}_{5}, \mathrm{~A}_{4}$ & 0.93 & 0.35 & 0 & 0.43 \\
\hline $\mathrm{A}_{5}, \mathrm{~A}_{6}$ & 0.25 & 0.197 & 0 & 0 \\
\hline $\mathrm{A}_{6}, \mathrm{~A}_{1}$ & 0 & 0.152 & 0 & 0 \\
\hline $\mathrm{A}_{6}, \mathrm{~A}_{2}$ & 0 & 0 & 0.15 & 0.25 \\
\hline$A_{6}, A_{3}$ & 0 & 0 & 0 & 0.25 \\
\hline $\mathrm{A}_{6}, \mathrm{~A}_{4}$ & 0 & 0.152 & 0.064 & 0.043 \\
\hline $\mathrm{A}_{6}, \mathrm{~A}_{5}$ & 0 & 0 & 0.15 & 0.045 \\
\hline
\end{tabular}

Tabel 14. Perhitungan Fungsi Preferensi Gabungan

\begin{tabular}{cccccccc}
\hline Alternatif & $\mathbf{A}_{\mathbf{1}}$ & $\mathbf{A}_{\mathbf{2}}$ & $\mathbf{A}_{\mathbf{3}}$ & $\mathbf{A}_{\mathbf{4}}$ & $\mathbf{A}_{\mathbf{5}}$ & $\mathbf{A}_{\mathbf{6}}$ & Total \\
\hline $\mathbf{A}_{\mathbf{1}}$ & - & 0.493 & 0.5 & 0.207 & 0.15 & 0.25 & $\mathbf{1 . 6}$ \\
$\mathbf{A}_{2}$ & 0.152 & - & 0.218 & 0.152 & 0 & 0.156 & $\mathbf{0 . 6 7 8}$ \\
$\mathbf{A}_{3}$ & 0.35 & 0.347 & - & 0.421 & 0.15 & 0.197 & $\mathbf{1 . 4 6 5}$ \\
$\mathbf{A}_{4}$ & 0 & 0.284 & 0.362 & - & 0.078 & 0.156 & $\mathbf{0 . 8 8}$ \\
$\mathbf{A}_{5}$ & 0.494 & 0.54 & 1 & 1.71 & - & 0.447 & $\mathbf{4 . 1 9 1}$ \\
$\mathbf{A}_{6}$ & 0.152 & 0.4 & 0.25 & 0.259 & 0.195 & - & $\mathbf{1 . 2 5 6}$ \\
Total & $\mathbf{1 . 1 4 8}$ & $\mathbf{2 . 0 6 4}$ & $\mathbf{2 . 3 3}$ & $\mathbf{2 . 7 4 9}$ & $\mathbf{0 . 5 7 3}$ & $\mathbf{1 . 2 0 6}$ & \\
\hline
\end{tabular}


Langkah 4 : Menentukan Entering Flow dan Leaving Flow dari outranking.

1. Leaving Flow (altenatif positif) $=\ddot{o}^{+}(i)=\frac{1}{n-1} \sum_{i^{\prime}=1}^{n}$ ð $\left(i, i^{\prime}\right)$

$$
\begin{aligned}
& \mathrm{A}_{1}=\frac{1}{6-1} \times 1.6=0.32 \\
& \mathrm{~A}_{2}=\frac{1}{6-1} \times 0.678=0.1356
\end{aligned}
$$

2. Entering Flow (alternatif negatif) $=\ddot{0}^{-}(i)=\frac{1}{n-1} \sum_{i^{\prime}=1}^{n}$ ð $\left(i^{\prime}, i\right)$

$$
\begin{aligned}
& \mathrm{A}_{1}=\frac{1}{6-1} \times 1.148=0.2296 \\
& \mathrm{~A}_{2}=\frac{1}{6-1} \times 2.064=0.4128
\end{aligned}
$$

Tabel 15. Hasil Leaving dan Entering Flow

\begin{tabular}{lcc}
\hline Alternatif & Leaving flow & Entering Flow \\
\hline $\mathrm{A}_{1}$ & 0.32 & 0.2296 \\
$\mathrm{~A}_{2}$ & 0.1356 & 0.4128 \\
$\mathrm{~A}_{3}$ & 0.293 & 0.466 \\
$\mathrm{~A}_{4}$ & 0.176 & 0.5498 \\
$\mathrm{~A}_{5}$ & 0.8382 & 0.1146 \\
$\mathrm{~A}_{6}$ & 0.2512 & 0.2412 \\
\hline
\end{tabular}

Langkah 5 : Menghitung total seluruh outranking (leaving dan entering flow) alternatif.

$\ddot{o}(i)=\ddot{o}^{+}(i)-\ddot{o}^{-}(i)$

$\mathrm{A}_{1}=0.32-0.2296=0.0904$

$\mathrm{A}_{2}=0.1356-0.4128=-0.2772$

$\mathrm{A}_{3}=0.293-0.466=-0.173$

$\mathrm{A}_{4}=0.176-0.5498=-0.3738$

$\mathrm{A}_{5}=0.8382-0.1146=0.7236$

$\mathrm{A}_{6}=0.2512-0.2412=0.01$

Langkah 6 : Melakukan perangkingan alternatif berdasarkan nilai outranking.

Tabel 16. Perangkingan Alternatif

\begin{tabular}{cccc}
\hline Alternatif & Outrangking flow & Peringkat & Keterangan \\
\hline $\mathrm{A}_{5}$ & 0.7236 & 1 & Pohon angsana \\
$\mathrm{A}_{1}$ & 0.0904 & 2 & Pohon Mahoni \\
$\mathrm{A}_{6}$ & 0.01 & 3 & Pohon flamboyan \\
$\mathrm{A}_{3}$ & -0.173 & 4 & Pohon tanjung \\
$\mathrm{A}_{2}$ & -0.2772 & 5 & Pohon trambesi \\
$\mathrm{A}_{4}$ & -0.3738 & 6 & Pohon akasia \\
\hline
\end{tabular}

Berdasarkan perhitungan alternatif di atas, maka $\mathrm{A}_{5}$ terpilih menjadi alternatif terbaik dalam pemilihan Pohon pelindung yaitu Pohon Angsana.

\section{KESIMPULAN}

Berdasarkan penulisan penelitian ini yang berjudul Sistem Pendukung Keputusan dalam menentukan jenis pohon pelindung yang akan ditanam dipinggir jalan Menerapkan Metode PROMETHEE II, maka kesimpulan yang diperoleh sebagai berikut:

1. Proses dalam menentukan jenis pohon pelindung harus disertai adanya kriteria dan alternatif, kriterianya yaitu Umur, Jenis Akar, Diameter pohon, Tinggi pohon dan alternatifnya yaitu Pohon mahoni, Pohon trambesi, Pohon tanjung, Pohon akasia, Pohon angsana, dan Pohon falmboyan.

2. Di dalam menggunakan Metode PROMETHEE II harus disertai kriteria dan alternatif, maka dapat hasil dari outrangking yang dapat mengurutkan dan memberi peringkat dalam melakukan pemilihan jenis pohon pelindung .

3. Sistem Pendukung Keputusan dalam menentukan jenis pohon pelindung yang akan ditanam dipinggir jalan pada Jenis Pohon Pelindung dibangun menggunakan Microsoft Visual Studio 2008 yang menghasilkan pemilihan jenis pohon pelindung berdasarkan kriteria yang telah ditentukan. Sistem yang dibangun membantu memberikan data sebagai bahan pertimbangan bersifat akurat dan lebih efesien.

\section{REFERENCES}

[1] P. W. Ananta and S. Winiarti, "Sistem Pendukung Keputusan Dalam Penilaian Kinerja Pegawai Untuk Kenaikan Jabatan Pegawai Menggunakan Metode Gap Kompetensi (Studi Kasus Perusahaan Perkasa Jaya Compuretail),” J. Sarj. Tek. Inform., vol. 1, no. 2, pp. 
574-583, 2013.

[2] H. Purwasih, S. Latifah, and A. Sukmana, “Identifikasi Jenis Tanaman di Beberapa Jalur Hijau Jalan Kota Medan,” Peronema For. Sci. J., vol. 2, no. 2, pp. 108-116, 2013.

[3] A. V. Manikrao and C. Shankar, "Facility Location Selection using PROMETHEE II Method," Int. Conf. Ind. Eng. Oper. Manag. Dhaka, pp. 59-64, 2010 .

[4] M. Wafi, R. S. Perdana, and W. Kurniawan, "Implementasi Metode Promethee II untuk Menentukan Pemenang Tender Proyek ( Studi Kasus : Dinas Perhubungan dan LLAJ Provinsi Jawa Timur ),” vol. 1, no. 11, pp. 1224-1231, 2017.

[5] Kusrini, Konsep dan Aplikasi Sistem Pendukung Keputusan. 2007.

[6] T. Limbong et al., Sistem Pendukung Keputusan: Metode \& Implementasi. Medan: Yayasan Kita Menulis, 2020.

[7] S. Kusumadewi, S. Hartati, A. Harjoko, and Retantyo Wardoyo, Fuzzy Multi-Attribute Decision Making (FUZZY MADM). 2006.

[8] T.-P. Turban, E., Aronson, J., \& Liang, Decision Support Systems And Inteligence System. US: Prentice-Hall, 2005.

[9] A. Harsono, H. Prassetyo, and N. Arqom, "Metode Pemilihan Pemasok Sayuran di Supermarket dengan Metode AHP dan PROMETHEE,” J. Itenas Rekayasa Inst. Teknol. Nas., pp. 184-195, 2009.

[10] C. Munte, "Sistem Pendukung Keputusan Penentuan Bidang Keahlian Karyawan Salon Kecantikan Dengan Menerapkan Metode PROMETHEE," vol. IV, no. September, pp. 46-52, 2014.

[11] F. Adelia, D. Wahyuli, T. Imanda, and A. Perdana, "Analisis Promethee II Pada Faktor Penyebab Mahasiswa Sulit Menemukan Judul Artikel Ilmiah," vol. 17, 2018.

[12] M. Mesran, I. Saputra, and M. Ariska, "Penerapan Metode Promethee Ii Pada Sistem Layanan Dan Rujukan Terpadu ( Slrt ) ( Studi Kasus : Dinas Sosial Kabupaten Deli Serdang )," KOMIK (Konferensi Nas. Teknol. Inf. dan Komputer), vol. I, pp. 276-285, 2017.

[13] M. Mesran, P. Pristiwanto, and I. Sinaga, "Implementasi Promethee II Dalam Pemilihan Pestisida Terbaik Untuk Perawatan Daun Pada Tanaman Cabe," CESS (Journal Comput. Eng. Syst. Sci., vol. 3, no. 2, pp. 46-53, 2018.

[14] T. Hunjak, Mathematical Foundations of the Methods for Multicriterial Decision Making. Mathematical Communications, 1997. 